\title{
Ekspresi PDGF-B dan SCUBE 1 pada Arteri Karotis Mencit yang Diligasi dan Tidak Diligasi
}

\author{
Ranti Verdiana ${ }^{1}$, Hirowati $\mathrm{Ali}^{2}$, Husnil Kadri ${ }^{2}$
}

\begin{abstract}
Abstrak
Diffuse Intimal Thickening (DIT)terjadi sebagai adaptasi fisologis terhadap shear stress yang dapat terbentuk melalui ligasi arteri karotis. Ligasi akan menyebabkan terbentuknya penebalan tunika intima pada pembuluh darah. Penebalan tunika intima terjadi melalui proses inflamasi yang melibatkan sitokin seperti PDGF-Bdan SCUBE 1 yang terdapat di dalam trombosit dan endotel. Tujuan penelitian adalah mengetahui ekspresi PDGF-B dan SCUBE 1 pada arteri karotis mencit yang diligasi dan tidak diligasi. Desain penelitian adalah eksperimental dengan menggunakan 5 ekor mencit yang dilakukan ligasi pada arteri karotis kiri sedangkan arteri karotis kanan tidak diligasi. Kemudian, arteri karotis tersebut dikumpulkan dan diperiksa kadar PDGF-B dan SCUBE 1 dengan menggunakan PCR. Uji hipotesis yang digunakan adalah independent $t$-test. Hasil penelitian adalah tidak terdapat perbedaan bermakna PDGF-B pada arteri karotis mencit yang diligasi dan tidak diligasi $(p=0,66 ; p>0,05)$ dan tidak terdapat perbedaan bermakna SCUBE 1 pada arteri karotis mencit yang diligasi dan tidak diligasi $(p=0,33 ; p>0,05)$.
\end{abstract}

Kata kunci: diffuse intimal thickening, DIT, PDGF-B, SCUBE 1, PCR.

\begin{abstract}
Diffuse Intimal Thickening (DIT) develops as physiological adaptive process of shear stress which can be performed by carotid artery ligation in mice. Ligation will cause an intimal thickening in vessel. Intimal thickening occurs through an inflammatory process that involves cytokines such as PDGF-B and SCUBE 1 that are found in platelet and endothelial cells. The objective of this study was to determine the expression of PDGF-B and SCUBE 1 in ligated and non ligated carotid artery of mice. The design study was experimental. This study used 5 mouse that were ligated in left carotid artery and non ligated in right carotid artery. Then, those carotid arteries were collected and examined PDGF-B and SCUBE 1 levels using PCR. The hypothesis test of this study was Independent $t$-test. The result was no significant difference between PDGF-B in ligated and non ligated carotid artery of mice $(p=0.66 ; p>0.05)$. The same result was also found in SCUBE 1 as well ( $p=0.33 ; p>0.05$ ).
\end{abstract}

Keywords: diffuse intimal thickening, DIT, PDGF-B, SCUBE 1, PCR.

Affiliasi penulis : 1. Pendidikan Dokter FK UNAND (Fakultas Kedokteran Universitas Andalas Padang), 2. Bagian Biokimia FK UNAND

Korespondensi : Hirowati Ali, E-mail: hirowati_ali@fk.unand.ac.id, Telp: 08170967781

\section{PENDAHULUAN}

Aterosklerosis merupakan penyebab utama penyakit arteri koroner. Penyakit arteri koroner merupakan penyebab kematian nomor satu di dunia sehingga harus dicegah. Walaupun banyak terapi untuk aterosklerosis yang sudah ditemukan, terapi tersebut hanya dapat mencegah $30-40 \%$ pasien terhadap risiko penyakit arteri koroner dan hingga saat ini belum ada terapi yang dapat menyembuhkan. ${ }^{1,2}$

Diffuse intimal thickening (DIT) merupakan suatu penebalan pada tunika intima pembuluh darah yang terutama terdiri dari sel otot polos, elastin, proteoglikan, sedikit makrofag dan tanpa adanya endapan lemak. DIT dapat terjadi sejak usia dini pada arteri manusia sebelum proses aterosklerosis dimulai. ${ }^{3}$ DIT terjadi pada arteri yang cenderung mengalami aterosklerosis, seperti aorta desenden, aorta abdominal, arteri karotis, arteri koroner dan arteri 
iliaka. Mekanisme yang tepat mengenai bagaimana terjadinya DIT belum diketahui. DIT mungkin terjadi sebagai adaptasi fisologis terhadap stres mekanik. Stres mekanik yang terjadi berupa shear stress pada pembuluh darah yang disebabkan oleh aliran darah. ${ }^{4,5}$

Shear stress yang berlangsung terus-menerus akan menyebabkan terjadinya trauma pada pembuluh darah. Trauma yang terjadi akan direspon oleh trombosit melalui granul trombosit yang mengandung salah satu faktor pertumbuhan, yaitu PDGF (PlateletDerived Growth Factor). PDGF mempunyai beberapa isoform, yaitu PDGF-A, PDGF-B, PDGF-C, dan PDGF-D.Akan tetapi, PDGF-B merupakan isoform utama yang ditemukan di dalam platelet. PDGF nantinya akan menyebabkan migrasi sel otot polos dari tunika media menuju tunika intima. Sel otot polos akan berproliferasi di dalam tunika intima. Hal ini yang nantinya dapat menyebabkan terjadinya DIT. ${ }^{6-8}$

Signal peptide-CUB-EGF domain-containing protein (SCUBE) merupakan suatu protein permukaan sel yang diekspresikan. SCUBE mempunyai tiga isoform, yaitu SCUBE 1 , SCUBE 2 , dan SCUBE $3 .^{9}$ SCUBE 2 merupakan target molekul baru pada aterosklerosis dan mungkin berperan dalam progresivitas plak melalui transduksi sinyal $\mathrm{Hh}$ (Hedgehog). SCUBE 1 dan 3 sudah diidentifikasi terdapat dalam pembuluh darah berbagai organ dan secara selektif diekspresikan oleh sel endotel dan trombosit. SCUBE 3 sudah terdeteksi dalam miokard yang mungkin terlibat dalam integritas miosit dan pertumbuhan sel. Fungsi biologis SCUBE 1 pada aterosklerosis atau pembentukan trombus masih belum jelas. ${ }^{10,11}$

SCUBE 1 merupakan suatu protein permukaan sel yang termasuk keluarga gen SCUBE. ${ }^{12}$ SCUBE 1 diekspresikan oleh trombosit dan sel endotelial pembuluh darah. ${ }^{13}$ Trombosit kemungkinan merupakan sumber utama yang mengekspresikan SCUBE 1 pada sistem vaskular. SCUBE 1 tersimpan di dalam a-granul saat trombosit dalam keadaan tidak aktif, kemudian akan berpindah ke permukaan trombosit seiring aktivasi trombosit oleh trombin saat terjadinya trauma. SCUBE 1 berperan dalam memediasi interaksi platelet-matriks dan aglutinasi platelet yang diinduksi ristocetin. Oleh karena itu, SCUBE 1 dapat dihubungkan dengan adanya trombus dan plak pada aterosklerosis. Penelitian terbaru mengatakan bahwa ekspresi SCUBE 1 meningkat pada pasien sindrom koroner akut dan stroke aterotrombosis pembuluh darah besar akut.9,14,15 Berdasarkan hal di atas, trombosit merupakan pemeran utama dalam terjadinya penebalan tunika intima. ${ }^{16}$

Berdasarkan uraian diatas, perlu dilakukan penelitian untuk melihat apakah SCUBE 1 sudah ada pada tahap DIT sehingga hal ini nantinya diharapkan bisa dijadikan deteksi awal sebelum terjadinya aterosklerosis dan bisa dijadikan suatu awal permulaan agar nantinya dilakukan penelitian lebih lanjut mengenai hal ini.

\section{METODE}

Ini adalah penelitian eksperimental dengan mencit sebagai hewan percobaan. Variabel dalam penelitian ini adalah PDGF-B danSCUBE 1. Penelitian ini dilakukan dari Maret 2014 sampai Januari 2015 di Gedung Biomedik, Laboratorium Biokimia, dan Laboratorium Hewan Fakultas Kedokteran Universitas Andalas.

Populasi yang digunakan adalah mencit putih jantan dengan galur Swiss webster berusia 10-15 minggu dengan berat badan 20-25 gram yang dibeli dari Laboratorium Farmakologi Fakultas Farmasi Universitas Andalas. Sampel yang digunakan adalah mencit putih jantan dengan kriteria inklusi dalam keadaan sehat, berumur 10-15 minggu dengan berat badan 20-25 gram, kriteria eksklusi adalah gerakan mencit tidak aktif, dan kriteria drop out adalah mencit mati pada masa penelitian. Jumlah mencit yang digunakan sebagai sampel disesuaikan dengan kriteria World Health Organization (WHO) tahun 2000, besar sampel minimal 5 ekor mencit untuk tiap kelompok. ${ }^{17}$ Setiap mencit akan digunakan arteri karotisnya dimana arteri karotis kanan tidak diligasi dan arteri karotis kiri diligasi. Setelah arteri karotis kiri diligasi selama 3 minggu, mencit dimatikan dengan dosis fenobarbital berlebih dan dilakukan pengambilan arteri karotis kanan dan kiri. Kemudian, dilakukan pemeriksaan PCR dengan menggunakan primer SCUBE 1 (F): 5'-CGCAAACTCTGGATCCAGTTC-3' dan (R): 5'-GAACATCTCCTTGGACTCCTGG-3' dengan panjang basa 249 bps, primer PDGF-B (F): 5'- 
TGCTGCTACCTGCGTCTGGTC-3' dan (R): 5'TTCTTTCGCACAATCTCAATC-3'dengan panjang basa 452 bps, dan primer GAPDH (F): 5'TGCATTTCAACACCTTGACC-3' dan (R): 5'CTGCAGATGCTGTGTCTGGT-3' dengan panjang basa 91 bps..11,18 Setelah itu, dilanjutkan dengan pemeriksaan elektroforesis, dan pemeriksaan di bawah sinar UV pada seluruh sampel. NCBI Image-J software digunakan untuk pengukuran ketebalan banddengan hasil berupa angka.

Analisis data dilakukan secara bertahap, yaitu dengan melakukan uji normalitas distribusi data. Bila distribusi data normal melalui uji shapiro wilk, maka dilanjutkan dengan analisa parametrik berupa independent t-test untuk mengetahui perbedaan ekspresi PDGF-B dan SCUBE 1 pada arteri karotis mencit yang diligasi dan tidak diligasi.

\section{HASIL}

Langkah pertama adalah melakukan uji normalitas data dengan uji shapiro wilk. Data terdistribusi normal jika $p>\alpha$ dimana $\alpha=0,05$. Dari hasil uji shapiro wilk, didapatkan nilai $p>0,05$ sehingga dikatakan data terdistribusi normal.

Untuk mengetahui perbedaan ekspresi PDGF-B dan SCUBE 1 pada arteri karotis mencit yang diligasi dan tidak diligasi dilakukan independent $t$-test (Tabel 1). Hasil dikatakan bermakna bila $p<0,05$ (hipotesis diterima).

Tabel 1. Ekspresi PDGF-B dan SCUBE 1 pada arterikarotis mencit yang diligasi dan tidak diligasi

\begin{tabular}{|c|c|c|c|c|}
\hline & Sampel & $n$ & Rerata \pm SD & $p$ \\
\hline \multirow[t]{3}{*}{ SCUBE1 } & Tidak & 5 & $1,26 \pm 1,09$ & \multirow[t]{3}{*}{0,33} \\
\hline & diligasi & & & \\
\hline & Ligasi & 5 & $0,70 \pm 0,27$ & \\
\hline \multirow[t]{3}{*}{ PDGF-B } & Tidak & 5 & $0,71 \pm 0,57$ & \multirow[t]{3}{*}{0,66} \\
\hline & diligasi & & & \\
\hline & Ligasi & 5 & $0,58 \pm 0,14$ & \\
\hline
\end{tabular}

Berdasarkan Tabel 1, dapat dilihat bahwa nilai $p=0,33(p>0,05)$ untuk SCUBE 1 ligasi dan tidak diligasi dan nilai $p=0,66(p>0,05)$ untuk PDGF-B ligasi dan tidak diligasi sehingga dapat disimpulkan bahwa tidak terdapat perbedaan signifikan antara SCUBE 1 ligasi dan tidak ligasi serta PDGF-B ligasi dan tidak diligasi.

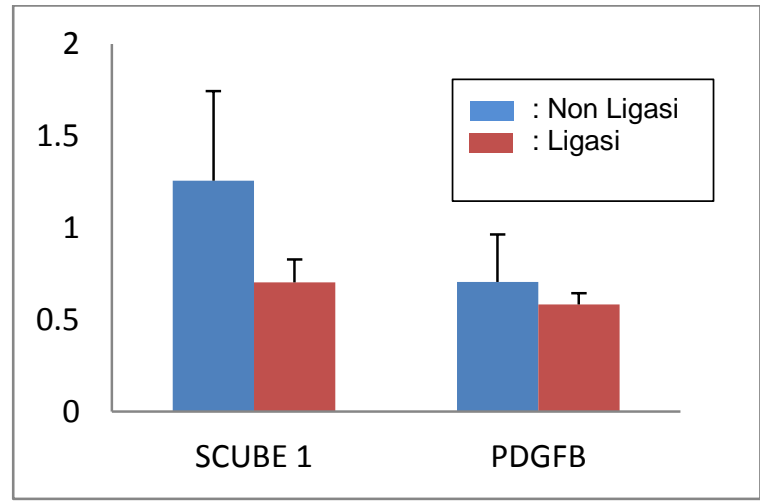

Gambar 1. Grafik ekspresi PDGF-B dan SCUBE 1 pada arteri karotis mencit yang diligasi dan tidak diligasi

Gambar 1 memperlihatkan grafik ekspresi PDGF-B dan SCUBE 1 pada arteri karotis mencit yang diligasi dan tidak diligasi. Tampak pada grafik tersebut terdapat tendensi penurunan ekspresi SCUBE 1 dan PDGF-B dari tidak diligasi ke ligasi walaupun secara analisis statistik didapatkan perbedaan yang tidak bermakna.

\section{PEMBAHASAN}

Diffuse Intimal Thickening (DIT) merupakan penebalan tunika intima yang terjadi sebagai adaptasi fisologis terhadap stres mekanik berupa shear stress. ${ }^{5}$ Salah satu cara yang digunakan adalah animal model melalui ligasi arteri karotis mencit. ${ }^{10}$ Ligasi pada arteri karotis dapat menyebabkan penyempitan parsial lumen pembuluh darah. Penyempitan ini akan mengakibatkan turbulensi aliran darah dan terjadinya shear stress yang menyebabkan trauma pada pembuluh darah hingga akhirnya terjadi penebalan tunika intima pembuluh darah. ${ }^{4,5}$

Pada penelitian ini tidak terdapat perbedaan yang signifikan antara SCUBE 1 ligasi dan tidak diligasi. Hal ini mungkin dikarenakan belum terjadinya peningkatan SCUBE 1 pada arteri karotis yang diligasi sebagai model DIT, seperti pada penelitian Dai et al yang dilakukan pada tahun 2008 mengatakan bahwa ekspresi SCUBE 1 meningkat pada aterosklerosis lanjut seperti pada pasien sindrom koroner akut dan stroke aterotrombosis pembuluh darah besar akut. ${ }^{14}$

Perbedaan yang signifikan juga tidak terlihat antara PDGF-B ligasi dan tidak diligasi. Hasil ini bertolak belakang dengan penelitian Jawien et al yang dilakukan pada tahun 1992 serta Lemstrom dan 
Koskinen pada tahun 1997 mengatakan bahwa PDGF-

B berperan dalam proses terjadinya DIT dengan menyebabkan migrasi sel otot polos tunika media menuju tunika intima. Kemudian, sel otot polos akan berproliferasi di dalam tunika intima sehingga menyebabkan terjadinya DIT. ${ }^{7,8}$ Penelitian Tang et al yang dilakukan pada tahun 2005 mengatakan bahwa PDGF dapat berperan sebagai antiinflamasi pada aterosklerosis sekaligus juga menstimulasi proliferasi sel otot polos pembuluh darah. Selain itu, penelitian tersebut juga menyatakan bahwa tidak adanya PDGF$B$ di dalam sirkulasi yang merupakan sumber utama PDGF pada lesi aterosklerosis, menyebabkan perubahan komposisi lesi, yaitu meningkatkan infiltrasi sel inflamasi. ${ }^{19}$ Penelitian Kozaki et al yang dilakukan pada tahun 2002 menyatakan bahwa eliminasi PDGF$B$ tidak akan menghambat akumulasi sel otot polos pada lesi. Kedua penelitian di atas mengenai eliminasi sebagian PDGF. Akan tetapi, pengaruh dari hambatan PDGF secara menyeluruh terhadap respon inflamasi dan akumulasi monosit, dapat berpotensi membatasi perluasan lesi. $^{20}$

Penelitian Nilsson et al pada tahun 1992 menyatakan bahwa kadar PDGF berhubungan dengan keparahan stenosis (penyempitan) dan tidak berhubungan dengan keparahan aterosklerosis koroner. Namun, hasil penelitian tersebut belum dapat disimpulkan bagaimana hubungan sebab akibat antara faktor pertumbuhan dan perkembangan aterosklerosis koroner. $^{21}$

Hasil penelitian ini sesuai dengan penelitian Jawien et al pada tahun 1992 dan Tu et al. Pada tahun 2008 yang menyatakan bahwa trombosit berperan dalam menghasilkan PDGF-B dan SCUBE 1 dimana menurut penelitian Huo dan Ley pada tahun 2004, trombosit berperan pada perkembangan aterosklerosis. $^{7,13,22}$ Oleh karena itu, tidak terjadinya peningkatan PDGF- B dan SCUBE 1 saat penebalan tunika intima, dikarenakan penebalan tunika intima merupakan proses inflamasi yang paling awal terjadi pada fase aterosklerosis dimana kemungkinan trombosit yang berperan masih sedikit jumlahnya sehingga belum mengakibatkan peningkatan PDGF-B dan SCUBE 1 yang signifikan seperti pada aterosklerosis lanjut.
Hal lain yang dapat mempengaruhi hasil pada penelitian ini adalah tidak dilakukannya pemeriksaan angiografi untuk melihat seberapa besar penyempitan yang terjadi sehingga belum dapat dipastikan apakah ukuran penyempitan arteri karotis kiri pada masingmasing tikus adalah sama.

\section{KESIMPULAN}

Terdapat ekspresi PDGF-B dan SCUBE 1 pada arteri karotis mencit yang diligasi. Terdapat ekspresi PDGF-B dan SCUBE 1 pada arteri karotis mencit yang tidak diligasi. Tidak terdapat perbedaan bermakna PDGF-B dan SCUBE 1 pada arteri karotis mencit yang diligasi dan tidak diligasi.

\section{UCAPAN TERIMA KASIH}

Ucapan terimakasih yang sedalam-dalamnya kepada staf Laboratorium Biokimia, staf Laboratorium Biomedik, dan staf Laboratorium Hewan atas bantuan dalam penelitian ini.

\section{DAFTAR PUSTAKA}

1. Soeharto I. Serangan jantung dan stroke hubungannya dengan lemak dan kolesterol. Edisi ke-2. Jakarta: PT. Gramedia Pustaka Utama; 2004.

2. Subbotin VM. Neovascularization of coronary tunica intima (DIT) is the cause of coronary atherosclerosis. Lipoproteins invade coronary intima via neovascularization from adventitial vasa vasorum, but not from the arterial lumen: a hypothesis. Theor Biol Med Model. 2012; 9(11):122.

3. Nakashima Y, Fujii H, Sumiyoshi S, Wight TN, Sueishi K. Early human atherosclerosis accumulation of lipid and proteoglycans in intimal thickenings followed by macrophage infiltration. Arterioscler Thromb Vasc Biol. 2007; 27:1159-65.

4. Nakashima Y, Wight TN, Sueishi K. Early atherosclerosis in humans: role of diffuse intimal thickening and extracellular matrix proteoglycans. Cardiovasc Res. 2008; 79:14-23.

5. Stary HC, Blankenhorn DH, Chandler AB, Glagov S, Insull W Jr, Richardson M, et al. A definition of the intima of human arteries and of its 
atherosclerosis-prone regions. A report from the committee on vascular lesions of the council on arteriosclerosis, American Heart Association. Circulation. 1992; 85:391-405.

6. Andrae J, Gallini R, Betsholtz C. Role of plateletderived growth factors in physiology and medicine. Genes Dev.2008;22:1276-312.

7. Jawien A, Pope DFB, Lindner V, Schwartz SM, Clowes AW. Platelet-derived growth factor promotes smooth muscle migration and intimal thickening in a rat model of balloon angioplasty. $\mathrm{J}$ Clin Invest. 1992;89:507-11.

8. Lemstrom KB, Koskinen PK.Expression and localization of platelet-derived growth factor ligand and receptor protein during acute and chronic rejection of rat cardiac allografts. Circulation. 1997;96:1240-9.

9. Tu CF, Su YH, Huang YN, Tsai MT, Li LT, Chen $\mathrm{YL}$, et al. Localization and characterization of a novel secreted protein SCUBE 1 in human platelets. Cardiovasc Res.2006;71(2006):486-95.

10. Ali H, Emoto N, Yagi K, Zellweger NV, Nakayama $\mathrm{K}$, Hatakeyama $\mathrm{K}$, et al. Localization and characterization of a novel secreted protein, SCUBE 2, in the development and progression of atherosclerosis. Kobe J Med Sci.2013;59(4):E12231.

11. Zhuang J, Deane JA, Yang RB, Li J, Ricardo SD. SCUBE 1, a novel developmental gene involved in renal regeneration and repair. Nephrol Dial Transplant.2009; 25:1421-8.

12. Ulusoy S, Ozkan G, Mentese A, Yavuz A, Karahan SC, Sumer AU.Signal peptide-CUB-EGF domaincontaining protein 1 (SCUBE1) level in hemodialysis patients and parameters affecting that level. Clin Biochem.2012;45:1444-9.

13. Tu CF, Yan YT, Wu SY, Djoko B, Tsai MT, Cheng $\mathrm{CJ}$, et al. Domain and functional analysis of a novel platelet-endothelial cell surface protein, SCUBE 1. J Biol Chem.2008;283(18):12478-88.
14. Dai DF, Thajeb $\mathrm{P}$, Tu CF, Chiang FT, Chen $\mathrm{CH}$, Yang RB, et al. Plasma concentration of SCUBE 1, a novel platelet protein, is elevated in patients with acute coronary syndrome and ischemic stroke. J Am Coll Cardiol.2008;22:2173-80.

15. Gunaydin M, Turkmen S, Sahin A, Sumer A, Mentese A, Turedi S, et al. The diagnostic value of SCUBE 1 levels in acute ischemic stroke. Turk $\mathrm{J}$ Biochem. 2014;39(1):107-12.

16. Fingerle J, Johnson R, Clowes AW, Majesky MW, Reidy MA. Role of platelets in smooth muscle cell proliferation and migration after vascular injury in rat carotid artery. Proc Natl Acad Sci USA.1989; 86: 8412-6.

17. World Health Organization. General guidelines for methodologies on research and evaluation of traditional medicine. Hong Kong; 2000.

18. Uhrbom L, Hesselager G, Nister M, Westermark B.Induction of brain tumors in mice using a recombinant Platelet-derived Growth Factor Bchain retrovirus. Cancer Res.1998;58:5275-9.

19. Tang J, Kozaki K, Farr AG, Martin PJ, Lindahl P, Betsholtz C, et al. The absense of platelet-derived growth factor-B in circulating cells promotes immune and inflammatory responses in atherosclerosis-prone ApoE-/- mice. Am J Pathol.2005;167(3):901-12.

20. Kozaki K, Kaminski WE, Tang J, Hollenbach S, Lindahl P, Sullivan C, et al. Blockade of plateletderived growth factor or its receptors transiently delays but does not prevent fibrous cap formation in ApoE null mice. Am J Pathol.2002;161(4): 1395407.

21. Nilsson J, Volk JS, Svensson J, Landou C, De FU, Hamsten A.Association between high levels of growth factors in plasma and progression of coronary atherosclerosis. J Intern Med.1992;232(5):397-404.

22. Huo Y, Ley KF. Role of platelets in the development of atherosclerosis. TCM.2004;14:18-22. 